\title{
SCIDOC
}

\author{
International Journal of Dentistry and Oral Science (IJDOS) \\ ISSN: $2377-8075$
}

\section{Evaluation Of The Clinical Effectiveness Of The Conometric Concept - A Systematic Review}

Review Article

Sanjana Nithyanandham ${ }^{1}$, Vinay Sivaswamy ${ }^{2 *}$, Lakshmi Thangavelu ${ }^{3}$

${ }^{1}$ Department of Prosthodontics, Saveetha Dental College, Saveetha Institute of Medical and Technical Sciences, Saveetha University, Chennai- 600077, India.

${ }^{2}$ Associate Professor, Department of Prosthodontics, Saveetha Dental College, Saveetha Institute of Medical and Technical Sciences, Saveetha University - Chennai - 600077, India.

${ }^{3}$ Associate Professor, Department of Pharmacology, Saveetha Dental College \& Hospitals, Saveetha University, Chennai, India.

\section{Abstract}

Background: ACone-in-cone Morse taper connection between abutments and crowns has been proposed to retain implantsupported definitive fixed dental prostheses(FDPs). This prosthetic approach, named the "Conometric Concept," was used to retain both lithium disilicate (LS2) and zirconia restorations. The conometric concept consists of a cone-in-cone connection between an abutment and the respective coping to retain an implant supported restoration without either screws or cement. The fit between abutment and the restoration is achieved with prefabricated components. The conical coupling abutments use the friction between the abutment and the titanium coping to retain a prosthesis without the use of cement. The restoration has no access holes and can be removed easily with a spring fixed partial denture remover. The emergence profile of the restoration can be placed sub-gingivally without the risk of cement remaining at the abutment coping interface. The main objective of this study is to critically review articles that have used conometric concept and to evaluate its clinical effectiveness. Materials And Method: An electronic search was performed in PubMed, Google scholar and Cochrane library till current date. The assessment of articles was done using predetermined selection criteria.Randomized, Non-randomized trials, prospective cohorts, prospective clinical trials and in vitro studies were included. Case series, case reports, conference paper and animalstudies were excluded from this review. The riskof bias was evaluated, and findings were synthesized.

Results: Out of the 7 included studies, 8 outcome measures have been identified. A meta-analysis was not feasible as none of the included studies were randomized control studies. 2 studies have analysed cumulative survival rate. Cumulative survival rate was in a range of $97.4 \%-100 \% .4$ studies have analysed mean probing depth. The range was $1.3 \mathrm{~mm}-2 \mathrm{~mm}$. One study analysed mean crestal bone boss. They gave a result of $0.4 \mathrm{~mm}$. 4 studies analysed the rate of framework fracture. The results were in a range of $0 \%-8.7 \%$. 4 studies analysed the aesthetic satisfaction and overall patient satisfaction and the results were in the range of $82 \%-91.8 \%$ and $79 \%-91 \%$ respectively. 4 studies have analysed mean probing depth. The range was $1.3 \mathrm{~mm}-2 \mathrm{~mm}$. Conclusion: Based on the findings of this review, it can be concluded that the conometric concept offers a promising clinical outcome as a prosthetic treatment option. Further long-term studies need to be conducted to evaluate its feasibility as a commercial treatment modality.

\section{Introduction}

Edentulism is the condition of being toothless to at least some degree. Loss of some teeth is called partial edentulism, whereas loss of all teeth is called complete edentulism.Edentulism can lead directly to impairment, functional limitation, physical, psychological, and social disability, and handicap [24, 16, 26, 29, 2].
The treatment options available are complete dentures, removable partial dentures, fixed partial dentures and implant supported prosthesis [9]. The treatment given to the patient depends on physiological, anatomical, and socio-economic status of the patient. The most common treatment option for long span edentulous areas are removable appliances. However, the degree of patient satisfaction tends to decrease during the first couple of years after insertion [30, 4, 19, 23].

*Corresponding Author:

Vinay Sivaswamy,

Associate Professor, Department of Prosthodontics, Saveetha Dental College, Saveetha Institute of Medical and Technical Sciences, Saveetha University - Chennai - 600077, India. Tel: 9176923110

Email ID: vinay.sdc@saveetha.com

Received: May 05, 2021

Accepted: June 20, 2021

Published: June 30, 2021

Citation: Sanjana Nithyanandham, Vinay Sivaswamy, Lakshmi Thangavelu. Evaluation Of The Clinical Effectiveness Of The Conometric Concept - A Systematic Review. Int J Dentistry Oral Sci. 2021;08(5):2918-2923. doi: http://dx.doi.org/10.19070/2377-8075-21000572

Copyright: Vinay Sivaswamy ${ }^{\circ} 2021$. This is an open-access article distributed under the terms of the Creative Commons Attribution License, which permits unrestricted use, distribution and reproduction in any medium, provided the original author and source are credited. 
Endosseous implants are commonly used to achieve dental prosthesis support and retention in both partially and completely edentulous patients $[21,3]$. Modern implantology marks a great treatment innovation since edentulism is a frequent situation, especially in elderly people. Different types of implant-supported prostheses are available, depending on the number and position of implants, prosthetic design and material and type of retainer. $[20,25,15,14]$.

Treatment options include removable or fixed implant-supported prosthesis. Removable implant-retained prosthesis consists in a removable prosthesis anchored to implants by different kinds of retainers [25]. On the other side, a fully stable dentition is achieved through implant-supported fixed dental prostheses only [27]. For this kind of restoration, two types of connections between implants and prostheses have been mainly used. They are screw-retained and cement retained connections. Both systems are good and predictable, but they could typically show some drawbacks. Screw-retained prosthesis offers tight retention, but shows more mechanical complications, such as screw loosening and fractures. Cement-retained prosthesis allow better aesthetics, but they showed more biological complications, such as soft tissue inflammation around the implant neck, residual cement, unretained prosthesis, dislodgement of prosthesis among a few [28, 31].

In 2018 Degidi et al, proposed using a cone-in-cone Morse taper connection between abutments and crowns to retain implantsupported definitive fixed dental prostheses. This Prosthetic approach, named the "Conometric Concept" was used to retain both lithium disilicate and zirconia restorations [1, 11, 12$]$.

The conometric concept consists of a cone-in-cone connection between an abutment and the respective coping to retain an implant supported restoration without either screws or cement. It has a tapered coping that is fixed to the prosthesis and inserted in a tapered abutment. The fit between abutment and the restoration is achieved with prefabricated components. The conical coupling abutments use the friction between the abutment and the titanium coping to retain a prosthesis without the use of cement. When an insertion force is applied, as the system is activated, the cervical margin of the coping is slightly deformed by wedge effects, causing elastic stress fields within both the coping and the abutment. Such stresses will partially remain even if the insertion force is removed $[10,11,6]$.

The use of cone-in-cone abutments to support definitive has given excellent short term prosthetic results [7]. Hence, the aim of this systematic review is to evaluate the clinical effectiveness of the conometric concept.

\section{Aim}

The aim of the current review is to evaluate the effectiveness and clinical efficiency of the conometric concept.

\section{Structured Question}

In cases requiring implants, is there a significant difference in effectiveness of the conometric abutment in comparison to conventional abutments?

\section{Pico Analysis}

Population: Healthy partially edentulous individuals with sufficient bone support for placement of implants.

Intervention: Implant crowns with conometric abutments.

Comparison: Implant crowns with conventional abutments.

\section{Outcome Measures:}

- Cumulative survival rate of the prosthesis- years

- Esthetics- Questionnaire

- Passive fit- Path of displacement $(\mathrm{mm})$

- Fracture resistance- Fatigue testing(N/cm)

- Crestal bone loss around the supporting implants

- Patient satisfaction- Questionnaire

- Vertical Fit of the framework- IOPAR

- Biofilm adherence to the crown- OHI index

\section{Data Collection And Analysis}

The data was collected from the studies that were included based on the author's name, publication year, study type, subjects, interventions, treatment time, method of measurements and outcomes assessed.

\section{Searched Databases}

The electronic databases that were included areNational Library of Medicine (PubMed), Google Scholar and the Cochrane database of systematic reviews. No limitation regarding publication date was included in the search. The electronic search was supplement by a manual search in the Journal of Prosthetic Dentistry, Journal of Prosthodontics, Clinical and Oral Implants related Research and the Clinical Oral Implant Journal.

\section{Search Protocol}

The search methodology employed was a combination of $\mathrm{MeSH}$ terms and Keywords. The keywords were categorized as Population, Intervention, Comparison, Outcome measures. Keywords within each group were combined using the Boolean operator(OR). The Boolean operator (AND) was used to combine all four categories together to attain the search results.

\section{Eligibility Criteria}

The title and abstract of the entries from the initial electronic database searches were read. Full text versions of the studies that could be potentially included in this review were read and a final selection was done according to the inclusion and exclusion criteria.

\section{Inclusion Criteria}

- Articles reporting cone in cone concept or conometric concept.

- Articles comparing conometric concept with other systems.

- Randomized control studies, Prospective clinical trials and In vitro studies 


\begin{tabular}{|c|c|}
\hline POPULATION & $\begin{array}{c}\text { Edentulous patients, partially edentulous patients, completely edentulous } \\
\text { patients, partially edentulous maxilla, partially edentulous mandible }\end{array}$ \\
\hline INTERVENTION & Conometric abutments, Cone in cone abutment connection, Acuris \\
\hline COMPARISON & $\begin{array}{r}\text { Cement retained prosthesis, Cement retained abutments, Screw retained } \\
\text { prosthesis, Screw retained abutments }\end{array}$ \\
\hline OUTCOME & $\begin{array}{c}\text { Passivity, Cumulative survival rate of the prosthesis, Crestal bone loss } \\
\text { around the supporting implants, Patient satisfaction, Esthetics, Fracture } \\
\text { resistance, Vertical fit of the framework, Biofilm adherence to the crown }\end{array}$ \\
\hline
\end{tabular}

\section{Exclusion Criteria}

- Review articles

- Case reports and series

- Animal studies

\section{Results}

The search strategy returned 22 articles from PubMed, 7 articles from Google scholar and 2 articles were handpicked. 18 clinical trials were included from the PubMed search of which 13 were excluded based on title and abstract and a total of 5 articles were selected. Of the 7 articles obtained from Google scholar, 5 were eliminated based on heading and abstract, and a total of 2 articles were selected. The total number of studies which were selected from the database were 9, of which 2 were eliminated as it did not meet the inclusion criteria and/or outcome measures and 7 articles were included based on core data. These 7 articles were reviewed and consolidated as given in the table below.

\section{Data Extraction}

The data of the selected studies were extracted using standardized abstraction tables. Information extracted from each study included the following in one table as general characteristics of the study.The outcome variables of the extracted data from the studies were interpreted in detail.The level of evidence for each included article was also tabulatedaccording to the Oxford Centre for Evidence-Based Medicine (March2009).

\section{Analysis}

Out of the 7 included studies, 8 outcome measures have been identified. However, a meta-analysis was not done as none of the included studies were randomized control studies. 2 studies have analyzed cumulative survival rate. Cumulative survival rate was in a range of $97.4 \%-100 \%[10,7]$. 4 studies have analyzed mean probing depth. The range was $1.3 \mathrm{~mm}-2 \mathrm{~mm}[13,11,5]$. One study analyzed mean crestal bone boss. They gave a result of $0.4 \mathrm{~mm}$ [7]. 4 studies analysed the rate of framework fracture. The results were in a range of $0 \%-8.7 \%$. 4 studies analysed the esthetic satisfaction and overall patient satisfaction and the results were in the range of $82 \%-91.8 \%$ and $79 \%-91 \%$ respectively $[10,7]$. 4 studies have analyzed mean probing depth. The range was $1.3 \mathrm{~mm}-2 \mathrm{~mm}$ $[13,11,5]$.

\section{Discussion}

Dental implantology is a reliable technique for treatment of partially and completely edentulous patients. The achievement of stable dentition is ensured by implant-supported fixed or removable dental prostheses. Titanium dental implants extended the treatment alternatives for edentulous patients using either implant-retained fixed or removable prostheses([8, 25]; 'Implant-Supported Rehabilitation of Completely and Partially Edentulous Patients', 2017).

A debate still exists within dentistry over the optimal connection between a fixed restoration and an implant. Screw retained restorations have less complications overall, but the failure rate of cement retained restorations was not influenced by cement choice. The presence of excess cement in cement retained restorations has increased association with incidence of peri-implant disease and bone loss. Conversely, the screw retained prosthesis is cost effective, as it facilitates prosthesis retrieval without the risk of damaging the prosthesis $[18,28,32,17]$.

The conometric concept involves the use of cone-in-cone morse tapered connection between the abutment and the prosthesis to retain an implant supported fixed dental prosthesis. The reported advantages of this concept are absence of cement and screws, simple maintenance, favorable emergence profile, and cost effectiveness [12].

The conical coupling abutments use friction between the abutment and the coping to retain the prosthesis without the use of cement. When an insertion force is applied, the system is activated. The cervical margin of the coping is slightly deformed by wedge effect, causing elastic stress fields within both the coping and the abutment. This stress will partially remain even if the insertion force is removed. This residual stress provides the retentive capability of the system [10-12].

According to a2 year prospective study by Degidi et al showed that Cone in cone approach was successful in 2 year followup with a mean probing depth of $2 \pm 0.90$, framework fracture of $8.7 \%$ and patient satisfaction of $79 \%$ [11].

In a 3 year prospective study done by Degidi et al, Titanium reinforced partial restorations with conic coupling retention supported by immediate implants provide a successful, cost effective treatment modality with a mean probing depth of $1.3 \pm 0.20$, framework fracture of $0 \%$ and patient satisfaction of $91 \%$ [13].

Another 3 year prospective study by Degidi et al stated that Conical abutment prostheses coupling connections were successful within the 3 -year timeframe of this study with a mean probing depth of $2 \pm 0.82$, framework fracture of $3 \%$ and patient satisfaction of $90 \%$ [13].

A 5 year prospective study done by the same author stated that Cone in cone connections was successful in 5 year followup with 
a cumulative survival rate of $97.4 \%$, framework fracture of $1.4 \%$ and patient satisfaction of $88 \%[10]$.

Bressan et al did a 2-year prospective study and noted that time and cost of treatment was reduced with conical crown concept. He noted a cumulative survival rate of $100 \%$, mean crestal bone loss of $-0.4 \pm 0.2$ and a patient satisfaction of $98 \%$ [7].

Another in-vitro study done by Bressan et al showed that there was minimal bacterial invasion in both internal conical and morse taper internal connection [5]. One of the major limitations in this review is the lack of randomised control trials comparing conometric coupling with other abutment prosthetic connections. Further studies are needed in this area to determine the effectiveness of conometric coupling as a routine retention modality in commercial dental implants.

\section{References}

[1]. Albiero AM, Benato R, Momic S, Degidi M. Guided-welded approach planning using a computer-aided designed prosthetic shell for immediately loaded complete-arch rehabilitations supported by conometric abutments. J Prosthet Dent. 2019 Dec;122(6):510-515.Pubmed PMID: 31078285.

[2]. Arita S, Gonda T, Togawa H, Maeda Y, Ikebe K. Influence of mandibular free-end partial edentulism on the force exerted on maxillary anterior teeth. J. Prosthodont. Res. 2020;64(4):454-9.

[3]. Bazrafshan N, Darby I. Retrospective success and survival rates of dental implants placed with simultaneous bone augmentation in partially edentulous patients. Clin Oral Implants Res. 2014 Jul;25(7):768-73.

[4]. Bird EJ. Long-term stability after treatment with removable appliances. Br. J. Orthod. 1983 Apr;10(2):101-5.

[5]. Bressan E, Stocchero M, Jimbo R, Rosati C, Fanti E, Tomasi C, et al. Microbial Leakage at Morse Taper Conometric Prosthetic Connection: An In Vitro Investigation. Implant Dent. 2017 Oct;26(5):756-761.Pubmed PMID: 28945671

[6]. Bressan E, Sbricoli L, Guazzo R, Bambace M, Lops D, Tomasi C. Five-year prospective study on conometric retention for complete fixed prostheses. Int J Oral Implantol (Berl). 2019;12(1):105-113.Pubmed PMID: 31116191.

[7]. Bressan, E. and Lops, D. (2014) 'Conometric retention for complete fixed prosthesis supported by four implants: 2-years prospective study', Clinical Oral Implants Research, pp. 546-552. doi: 10.1111/clr.12121.

[8]. Bretz, W. A. Long-term therapy with the ITI implant system is a reliable therapy for partially edentulous patients. J. Evid. Based Dent. Pract.2002: 287-288.

[9]. Budtz-Jörgensen E. Restoration of the partially edentulous mouth--a comparison of overdentures, removable partial dentures, fixed partial dentures and implant treatment. J Dent. 1996 Jul;24(4):237-44. Pubmed PMID: 8783527.

[10]. Degidi M, Nardi D, Gianluca S, Piattelli A. The Conometric Concept: A 5-Year Follow-up of Fixed Partial Monolithic Zirconia Restorations Supported by Cone-in-Cone Abutments. Int J Periodontics Restorative Dent. 2018 May/Jun;38(3):363-371.Pubmed PMID: 29641625.

[11]. Degidi M, Nardi D, Sighinolfi G, Degidi D, Piattelli A. The Conometric Concept: A Two-Year Follow-Up of Fixed Partial CEREC Restorations Supported By Cone-In-Cone Abutments. J Prosthodont. 2019 Feb;28(2):e780e787.Pubmed PMID: 30295374.

[12]. Degidi M, Nardi D, Sighinolfi G, Degidi D. The conometric concept for the definitive rehabilitation of a single posterior implant by using a conical indexed abutment: A technique. J Prosthet Dent. 2020 Apr;123(4):576579.Pubmed PMID: 31353114.
[13]. Degidi M, Nardi D, Piattelli A. The Conometric Concept: Coupling Connection for Immediately Loaded Titanium-Reinforced Provisional Fixed Partial Dentures-A Case Series. Int J Periodontics Restorative Dent. 2016 May-Jun;36(3):347-54.Pubmed PMID: 27100804.

[14]. Shetty M, Kalra R, Desai H, Hegde R. Esthetic rehabilitation of a partially edentulous patient with implants and tooth-supported fixed prosthesis. J Dent Implant. 2019 Jul 1;9(2):83.

[15]. Abd El_Wahab AY, Ahmed AG, Tolba EM. Evaluation of patient satisfaction and prosthetic maintenance of fixed detachable prosthesis used as treatment modality in completely edentulous patient. Egypt Dent J. $2018 \mathrm{Apr}$ 1;64(2-April (Fixed Prosthodontics, Dental Materials, Conservative Dentistry \& Endodontics)):1531-7.

[16]. Felton DA. Complete Edentulism and Comorbid Diseases: An Update. J Prosthodont. 2016 Jan;25(1):5-20.Pubmed PMID: 26371954.

[17]. Gaddale R, Mishra SK, Chowdhary R. Complications of screw- and cement-retained implant-supported full-arch restorations: a systematic review and meta-analysis. Int J Oral Implantol (Berl). 2020;13(1):11-40.Pubmed PMID: 32186285.

[18]. Shetty S, Garg A, Shenoy KK. Principles of screw-retained and cement-retained fixed implant prosthesis: A critical review. J. Interdiscip. Dent. 2014 Sep 1;4(3):123.

[19]. Graber, T. M. Long term stability after treatment with removable appliances. Am. J. Orthod.1984:363.

[20]. Gray, S. Success of short implants in patients who are partially edentulous. J Am Dent Assoc. 2013: 59-60.

[21]. Hagi D, Deporter DA, Pilliar RM, Arenovich T. A targeted review of study outcomes with short $(<$ or $=7 \mathrm{~mm}$ ) endosseous dental implants placed in partially edentulous patients. J Periodontol. 2004 Jun;75(6):798-804.Pubmed PMID: 15295944.

[22]. 'Implant-Supported Rehabilitation of Completely and Partially Edentulous Patients' (2017) Decision Making in Dental Implantology: Atlas of Surgical and Restorative Approaches, pp. 205-324. doi: 10.1002/9781119225973. ch5.

[23]. Jeyavalan MI, Narasimman M, Venkatakrishnan CJ, Philip JM. Management of long span partially edentulous maxilla with fixed removable denture prosthesis. Contemp. Clin. Dent. 2012 Jul;3(3):314.

[24]. De Marchi RJ, Hugo FN, Hilgert JB, Padilha DM. Association between number of teeth, edentulism and use of dentures with percentage body fat in south Brazilian community-dwelling older people. Gerodontology. 2012 Jun;29(2):e69-76.Pubmed PMID: 21054508.

[25]. Misch, C. E. Treatment Plans for Partially and Completely Edentulous Arches in Implant Dentistry. Dental Implant Prosthetics.2015:461-476.

[26]. Al Moaleem MM, Somaili DM, Ageeli TA, Namis SM, Mobarki AH, Mohamed MS, et al. Pattern of partial edentulism and its relation to age, gender, causes of teeth loss in Jazan population. Am. J. Health Res. 2016 Aug 26;4(5):121-6.

[27]. Pylant T, Triplett RG, Key MC, Brunsvold MA. A retrospective evaluation of endosseous titanium implants in the partially edentulous patient. Implant Dent. 1993 Apr 1;2(1):54.

[28]. Ragauskaite A, Žekonis G, Žilinskas J, Gleiznys A, Ivanauskienè E, Gleiznys $D$. The comparison of cement- and screw-retained crowns from technical and biological points of view. Stomatologija. 2017;19(2):44-50.Pubmed PMID: 29243683.

[29]. Şakar O. Current Status on Partial Edentulism and Removable Partial Dentures. Removable Partial Dentures 2016:3-8.

[30]. Tang EL, Wel SH. Assessing treatment effectiveness of removable and fixed orthodontic appliances with the occlusal index. Am J Orthod Dentofacial Orthop. 1990 Dec 1;98(6):550-6.

[31]. Vahey BR, Sordi MB, Stanley K, Magini RS, Novaes de Oliveira AP, Fredel $\mathrm{MC}$, et al. Mechanical integrity of cement- and screw-retained zirconiumlithium silicate glass-ceramic crowns to Morse taper implants. J Prosthet Dent. 2018 Nov;120(5):721-731.Pubmed PMID: 30093122.

[32]. Wittneben JG, Joda T, Weber HP, Brägger U. Screw retained vs. cement retained implant-supported fixed dental prosthesis. Periodontology 2000. 2017 Feb;73(1):141-51. 


\section{APPENDIX}

Figure 1: Flow Chart Depicting the search methodology describing the total number of articles obtained, the ones excluded, inclusion of handpicked articles and finally the total number of articles that were retrieved for analysis.

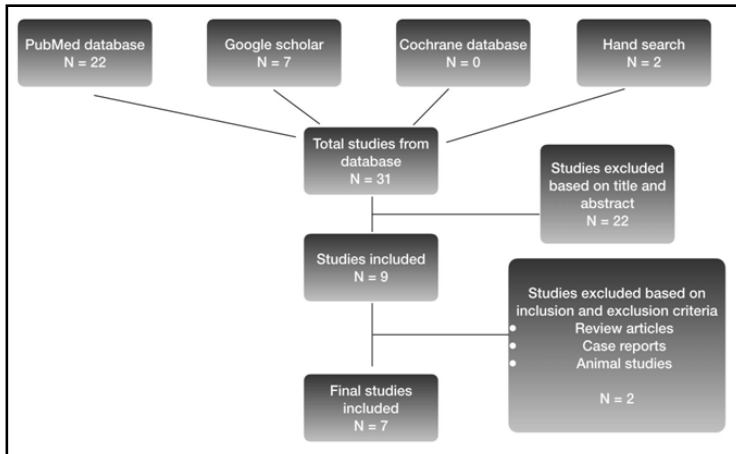

Table 1. Showing the studies that have been excluded.

\begin{tabular}{|c|c|c|c|c|}
\hline S No & Author & Year & Type of study & Reason for exclusion \\
\hline 1 & Alghamdi O & 2020 & Prospective study & Did not include conometric abutments \\
\hline 2 & Waller T et al & 2020 & Randomised control trial & Did not include conometric abutments \\
\hline 3 & Yao KT et al & 2020 & Pilot study & Did not include conometric abutments \\
\hline 4 & Degidi M et al & 2020 & Review article & Review \\
\hline 5 & Benjaboonyazit K & 2019 & In-vitro study & Did not include conometric abutments \\
\hline 6 & Alsheri et al & 2017 & In-vitro study & Did not include conometric abutments \\
\hline 7 & Albiero AM et al & 2018 & Review article & Review \\
\hline 8 & Gehrke SA & 2019 & In-vitro study & Did not include conometric abutments \\
\hline 9 & Szyszkowshi et al & 2019 & Randomised control trial & Did not include conometric abutments \\
\hline
\end{tabular}

Table 2. Shows Outcome Measures evaluated in this systematic review.

\begin{tabular}{|c|c|}
\hline S.no & Outcome Measurements \\
\hline 1 & Cumulative survival rate of the prosthesis- years \\
\hline 2 & Aesthetics- Questionnaire \\
\hline 3 & Patient satisfaction (Questionnaire) \\
\hline 4 & Crestal bone loss around the supporting implants \\
\hline 5 & Vertical Fit of the framework- IOPAR \\
\hline 6 & Biofilm adherence to the crown- PI index \\
\hline
\end{tabular}

Table 3. Shows a summary of all included articles in the systematic review and outcome measures.

\begin{tabular}{|c|c|c|c|c|c|c|}
\hline S.no & Author\&Year & Groups & $\begin{array}{c}\text { No. of } \\
\text { Implants }\end{array}$ & $\begin{array}{c}\text { Brand of Im- } \\
\text { plants }\end{array}$ & $\begin{array}{c}\text { So. of years } \\
\text { of study }\end{array}$ \\
\hline 1 & Degidi, 2016 & I group & 78 & Ankylos, Dentsply & Meazure 2.0 Build 158 & 3 years \\
\hline 2 & Bressan, 2013 & 1 group & 100 & Ankylos, Dentsply & MIWin 2.24 & 2 years \\
\hline 3 & Degidi, 2019 & 1 group & 50 & Ankylos, Dentsply & InLab software v.4.2 & 2 years \\
\hline 4 & Degidi, 2018 & 1 group & 134 & Ankylos, Dentsply & Meazure 2.0 Build 158 & 5 years \\
\hline 5 & Degidi, 2016 & 1 group & 130 & Ankylos, Dentsply & SPSS 20 & 3 years \\
\hline 6 & Bressan, 2019 & 1 group & 100 & - & & 5 years \\
\hline 7 & Bressan, 2017 & $\begin{array}{c}\text { Groups A - Internal } \\
\text { conical connection } \\
\text { Group B - Morse taper } \\
\text { internal connection }\end{array}$ & 24 & Ankylos, Dentsply & - & - \\
\hline
\end{tabular}


Table 4. Contains a compilation of data and statistics in the articles included as part of the systematic review.

\begin{tabular}{|c|c|c|c|c|c|c|}
\hline Author\&Year & Groups & $\begin{array}{c}\text { Sample } \\
\text { size }\end{array}$ & $\begin{array}{c}\begin{array}{c}\text { Type of } \\
\text { study }\end{array} \\
\end{array}$ & $\begin{array}{c}\text { Type of statistical } \\
\text { method used }\end{array}$ & Outcome Assessment & Inference \\
\hline Degidi, 2016 & I group & 67 & $\begin{array}{l}\text { Prospec- } \\
\text { tive study }\end{array}$ & Pearson correlation & $\begin{array}{c}\text { Mean Probing depth measure- } \\
\text { ments }(\mathrm{mm}) \\
1.3 \pm 0.2 \mathrm{~mm} \\
\text { Esthetics } \\
91 \% \\
\text { Framework fracture } \\
0 \% \\
\text { Patient satisfaction } \\
91 \%\end{array}$ & $\begin{array}{l}\text { Titanium reinforced } \\
\text { partial restorations } \\
\text { with conic coupling } \\
\text { retention supported } \\
\text { by immediate implants } \\
\text { provide a successful, } \\
\text { cost effective treat- } \\
\text { ment modality. }\end{array}$ \\
\hline Bressan, 2013 & 1 group & 25 & $\begin{array}{l}\text { Prospec- } \\
\text { tive study }\end{array}$ & $\begin{array}{l}\text { KolmogorovSmirnov test } \\
\text { McNemar test }\end{array}$ & $\begin{array}{c}\text { Cumulative survival rate } 100 \% \\
\text { Mean crestal Bone loss } \\
-0.4 \pm 0.2 \\
\text { Patient satisfaction } \\
98 \%\end{array}$ & $\begin{array}{l}\text { Reduced time and } \\
\text { cost of treatment with } \\
\text { conical crown concept }\end{array}$ \\
\hline Degidi, 2019 & 1 group & 25 & $\begin{array}{l}\text { Prospec- } \\
\text { tive study }\end{array}$ & $\begin{array}{l}\text { Kaplan-Meier analysis } \\
\text { Shapira-Wilk test } \\
\text { Friedman test } \\
\text { Bonferroni corrected Wil- } \\
\text { coxon paired sign-rank test } \\
\text { Pearson correlation }\end{array}$ & $\begin{array}{c}\text { Mean probing depth } \\
2 \pm 0.90 \mathrm{~mm} \\
\text { Framework fracture } \\
8.70 \% \\
\text { Patient satisfaction } \\
79 \% \\
\text { Esthetics } \\
82 \%\end{array}$ & $\begin{array}{c}\text { Cone in cone approach } \\
\text { was successful in } 2 \\
\text { year follow-up. }\end{array}$ \\
\hline Degidi, 2018 & 1 group & 78 & $\begin{array}{l}\text { Prospec- } \\
\text { tive study }\end{array}$ & $\begin{array}{c}\text { Shapira-Wilk test } \\
\text { Friedman test } \\
\text { Bonferroni corrected Wil- } \\
\text { coxon paired sign-rank test } \\
\text { Pearson correlation }\end{array}$ & $\begin{array}{c}\text { Cumulative survival rate } \\
97.40 \% \\
\text { Esthetics } \\
90.10 \% \\
\text { Patient satisfaction } \\
88 \% \\
\text { Framework fracture } \\
1.40 \% \\
\end{array}$ & $\begin{array}{l}\text { Cone in cone connec- } \\
\text { tions was successful in } \\
5 \text { year follow-up. }\end{array}$ \\
\hline Degidi, 2016 & 1 group & 65 & $\begin{array}{l}\text { Prospec- } \\
\text { tive study }\end{array}$ & $\begin{array}{c}\text { Shapira-Wilk test } \\
\text { Friedman test } \\
\text { Bonferroni coorected Wil- } \\
\text { coxon paired sign-rank test } \\
\text { Pearson correlation }\end{array}$ & $\begin{array}{c}\text { Mean probing depth } \\
2 \pm 0.82 \mathrm{~mm} \\
\text { Framework fracture } \\
3 \% \\
\text { Patient satisfaction } \\
90 \% \\
\text { Esthetics } \\
91.80 \%\end{array}$ & $\begin{array}{l}\text { Conical abutment } \\
\text { prostheses coupling } \\
\text { connections were } \\
\text { successful within the } \\
\text { 3-year timeframe of } \\
\text { this study }\end{array}$ \\
\hline Bressan, 2019 & 1 group & 25 & $\begin{array}{l}\text { Prospec- } \\
\text { tive study }\end{array}$ & Chi square test & $\begin{array}{c}\text { Mean probing depth } \\
1.4 \pm 0.5 \mathrm{~mm} \\
\text { Patient satisfaction } \\
85 \% \\
\text { PI Index } \\
1-31 \% \\
2-36 \% \\
3-61 \% \\
\end{array}$ & $\begin{array}{l}\text { Conometric retention } \\
\text { system can be used to } \\
\text { give fixed retention } \\
\text { to a complete pros- } \\
\text { thesis supported by } 4 \\
\text { implants. }\end{array}$ \\
\hline Bressan, 2017 & $\begin{array}{c}2 \text { groups } \\
\text { Group A - Internal } \\
\text { conical connection implant } \\
\text { Group B - Morse taper inter- } \\
\text { nal connection implant }\end{array}$ & 24 & $\begin{array}{l}\text { In-vitro } \\
\text { study }\end{array}$ & Fisher exact test & $\begin{array}{c}\text { Bacterial amount } \\
\text { Group A - 4.23X105 } \\
\text { Group B - 3.45X105 } \\
\text { Real time PCR } \\
\text { Group A - +ve in } 4 \text { out of } 10 \\
\text { Group B - + ve in } 6 \text { out of } 10\end{array}$ & $\begin{array}{l}\text { Minimal bacte- } \\
\text { rial infiltration in both } \\
\text { systems. }\end{array}$ \\
\hline
\end{tabular}

Table 5. Showing levels of evidence of included articles.

\begin{tabular}{|c|c|c|c|}
\hline S No & Included articles & Study design & CEBM levels of evidence \\
\hline 1 & Degidi, 2016 & Prospective study & Level 1b \\
\hline 2 & Bressan, 2013 & Prospective study & Level 1b \\
\hline 3 & Degidi, 2019 & Prospective study & Level 1b \\
\hline 4 & Degidi, 2018 & Prospective study & Level 1b \\
\hline 5 & Szyszkowski, 2019 & Randomised control trial & Level 1b \\
\hline 6 & Bressan, 2017 & In-vitro study & Level 5 \\
\hline
\end{tabular}

Table 6. Showing Risk of Bias in included studies.

\begin{tabular}{|c|c|c|}
\hline S No & Included articles & Risk of Bias \\
\hline 1 & Degidi, 2016 & Low risk \\
\hline 2 & Bressan, 2013 & Low risk \\
\hline 3 & Degidi, 2019 & Low risk \\
\hline 4 & Degidi, 2018 & Low risk \\
\hline 5 & Szyszkowski, 2019 & High risk \\
\hline 6 & Bressan, 2017 & Low risk \\
\hline
\end{tabular}

